\title{
Virulence Analysis of Wheat Powdery Mildew (Blumeria graminis f. sp. tritici) and Effective Genes in Middle Delta, Egypt
}

\author{
Moustafa M. El-Shamy, Wheat Diseases Research Dept., Plant Diseases Research Institute, ARC, Giza, Egypt; Hassan M. Emara, Botany \\ Department, Faculty of Science Benha University, Egypt; and Mona E. Mohamed, Wheat Diseases Research Dept., Plant Diseases Research \\ Institute, ARC, Giza, Egypt
}

\begin{abstract}
El-Shamy, M. M., Emara, H. M., and Mohamed, M. E. 2016. Virulence analysis of wheat powdery mildew (Blumeria graminis f. sp. tritici) and effective genes in Middle Delta, Egypt. Plant Dis. 100:1927-1930.

Wheat powdery mildew (Blumeria graminis $\mathrm{f}$. sp. tritici) has increased in Delta Egypt in recent years as a result of growing susceptible cultivars of bread wheat. Fifty-two isolates of $B$. graminis f. sp. tritici collected in 2013 and 2014 from commercial fields in five provinces were analyzed for virulence, using 21 genes conferring resistance to powdery mildew ( $P m$ genes) as well as 12 local wheat cultivars. First true leaves of 10day-old wheat differentials were inoculated with isolates derived from a single pustule of $B$. graminis $\mathrm{f}$. sp. tritici. No virulence to the resistance genes Pm3d, Pm12, Pm16, Pm24,Pm35, Pm36, and Pm37 was detected,

indicating that these genes could be used for resistance breeding. Virulence to Pm2, Pm4a, and Pm6 was low, while high virulence to genes $P m 1$ a, $P m 3 a, P m 3 c, P m 3 f, P m 5 a, P m 7, P m 8, P m 9$, and $P m 17$ was found, indicating that breeders should be very cautious in using these genes. At the adult stage, genes Pm2, Pm3d, Pm3f, Pm4a, Pm6, Pm12, Pm16, Pm17, Pm24, Pm35, Pm36, and Pm37 were completely effective in both years. All the tested Egyptian wheat cultivars were susceptible under natural field conditions. The virulence of $B$. graminis $\mathrm{f}$. sp. tritici population and resistance $P m$ genes have been assessed for the first time in Egypt
\end{abstract}

Powdery mildew, Blumeria graminis f. sp. tritici, causes infections of varying intensity in wheat cultivars worldwide. In susceptible wheat cultivars and under weather conditions favorable to the pathogen, infection may become so severe that powdery mildew covers the leaf surface and may reduce the number of grains. Powdery mildew can lead to reduction in yield, e.g., 10 to $62 \%$ in Brazil (Costamilan 2005), 48\% in Canada (Maxwell et al. 2009), 10 to $18 \%$ in Egypt (El-Shamy et al. 2012), and 10 to $30 \%$ in China (Huang et al. 2013). Utilization of resistant cultivars is the most economical and environmentally friendly approach to control the disease, enabling reductions in fungicide. Race-specific resistance genes have been widely used in wheat breeding programs to control this disease, but the selection pressure exerted by new cultivars results in the rapid emergence of new pathotypes with the corresponding virulence genes (Liu et al. 2001). The pathogen B. graminis f. sp. tritici has the ability to overcome single gene resistance rapidly through introducing new virulence. Therefore, there is a need for different forms of genetic resistance with greater durability (Peusha et al. 2000; Szunics and Szunics 1999). Therefore, large scale surveys of the virulence of the $B$. graminis $\mathrm{f}$. sp. tritici population are needed to identify effective resistance genes and detecting virulence changes and geographic distribution of pathogen population. These surveys also help to select resistance sources to be used in wheat breeding programs (Niewoehner and Leath 1998). Broadening of the genetic base of cultivated wheat by the introgression of resistance genes from related species or genera may provide new sources of useful and durable resistance against this disease. Genes from Triticum dicoccoides have been successfully transferred into hexaploid wheat (Reader and Miller 1991). Adult plant resistance retards infection, growth, and reproduction of B. graminis f. sp. tritici in adult plants but not in seedlings (Chen et al. 2009) and is more durable than race-specific resistance. In Egypt, the disease appeared in the last few years with high disease severities on most of the common wheat cultivars, especially in the Gharbia

Corresponding author: M. M. El-Shamy; E-mail: Dr.Elshamy@yahoo.com

Accepted for publication 5 May 2016.

http://dx.doi.org/10.1094/PDIS-01-16-0130-RE

(C) 2016 The American Phytopathological Society province, Delta Egypt. The objective of this work was to detect genetic variability of $B$. graminis f. sp. tritici isolates collected from Delta Egypt, the effectiveness of some differential wheat resistance genes, and to evaluate resistance of some Egyptian bread wheat cultivars to powdery mildew disease.

\section{Materials and Methods}

Wheat materials. A set of 21 differentials of wheat lines carrying known powdery mildew resistance genes ( $P m$ genes) was provided by C. Cowger, small grains pathologist, United States Department of Agriculture-Agricultural Research Service (USDA-ARS), Department of Plant Pathology, North Carolina State University (Raleigh, NC) (Table 1). Pedigree of these powdery mildew lines is listed according to Alam et al. (2011). Twelve registered Egyptian wheat cultivars obtained from the International Wheat Program, Crops Research Institute, Agricultural Research Centre (ARC), Giza were used in this study (Table 2).

Survey of wheat powdery mildew. A total of 52 samples of infected leaves by $B$. graminis f. sp. tritici were collected from the commercial fields of five provinces in Delta Egypt, i.e., Gharbia, Menoufia, Qalubia, Behera, and Dakahlia in 2013 and 2014.

Virulence of $B$. graminis $\mathbf{f}$. sp. tritici isolates. This work was carried out in a conditioned greenhouse, under temperatures ranging from 24 to $28^{\circ} \mathrm{C}$ at Gemmeiza ARC, Egypt. Powdery mildew colonies were initially transferred on the first expanded leaves of 10day-old plants of the susceptible cultivar Chancellor grown in pots $(10 \times 10 \mathrm{~cm}$ diameter) for each isolate. The inoculated plants were placed inside a glass chamber during the period of inoculum increase. A single colony for each isolate was transferred, using the spatula method on 10-day-old 'Chancellor' plants for multiplication. After 8 days, each isolate was characterized for virulence, using 21 differential hosts carrying known resistance genes as well as the local cultivars, by the brushing method, in which infected seedlings are rubbed gently over the healthy plants to be inoculated (Browder 1972; Mago et al. 2011). Disease assessment was carried out using a 0 to 9 scale (Leath and Heun 1990) in which $0=$ immune, no visible signs or symptoms, $1=$ highly resistant, small flecks only, $2=$ resistant, chlorotic flecks evident, $3=$ resistant, large flecks with chlorosis and necrosis, 4 = intermediate, mycelium and conidia barely detectable, $5=$ moderately susceptible, small to moderate-sized pustules and conidia present, $6=$ moderately susceptible, predominance of 
moderate-sized pustules and conidia present, $7=$ susceptible, at least $50 \%$ of the leaf covered with large pustules and conidia, $8=$ susceptible, 75 to $80 \%$ of the leaf covered with large pustules and conidia, and $9=$ susceptible, $100 \%$ of the leaf segment covered with large pustules and conidia.

The virulence/avirulence formula of each pathotype was detected based on the responses of each powdery mildew line (Green 1966). However, the pathotype virulence on the tested $P m$ genes was estimated according to Samborski and Dyck (1976), while gene efficacy was calculated according to Green (1966) as follows:

$$
\% \text { Virulence of isolate }=\frac{\text { No. of susceptible genes }}{\text { Total No. of the tested genes }} \times 100
$$

Table 1. Designated gene name, accession number, chromosomal position and source, used in this study

\begin{tabular}{|c|c|c|c|c|}
\hline $\begin{array}{l}\text { Host } \\
\text { differential }\end{array}$ & $\begin{array}{c}\text { Resistance } \\
\text { gene }\end{array}$ & $\begin{array}{c}\text { Accession } \\
\text { number }\end{array}$ & Position & Source \\
\hline $\begin{array}{l}\text { Axminster/ } \\
8^{*} \mathrm{Ccy}\end{array}$ & Pmla & CI 14114 & $7 \mathrm{AL}$ & $\begin{array}{l}\text { Triticum } \\
\text { aestivum }\end{array}$ \\
\hline $\mathrm{Ulka} / 8 * \mathrm{Cc}$ & $P m 2$ & CI 14118 & 5DS & $\begin{array}{l}\text { T. aestivum/ } \\
\text { Aegilops } \\
\text { tauschii }\end{array}$ \\
\hline Asosan $/ 8 * \mathrm{Cc}$ & $P m 3 a$ & CI 14120 & $1 \mathrm{AS}$ & T. aestivum \\
\hline Chull/8* Cc & $P m 3 b$ & CI 14121 & $1 \mathrm{AS}$ & T. aestivum \\
\hline Sonora/8* Cc & $P m 3 c$ & CI14122 & $1 \mathrm{AS}$ & T. aestivum \\
\hline Ralle & $P m 3 d$ & None & $1 \mathrm{AS}$ & T. aestivum \\
\hline $\operatorname{Pm} 3 f$ & $\operatorname{Pm} 3 f$ & CI15888 & $1 \mathrm{AS}$ & T. aestivum \\
\hline $\mathrm{Pm} 4 a$ & $P m 4 a$ & CI14124 & $2 \mathrm{AL}$ & T. dicoccum \\
\hline Ronos & $P m 4 b$ & None & $2 \mathrm{AL}$ & T. carthlicum \\
\hline$P m 5 a$ & $P m 5 a$ & CI14125 & $7 \mathrm{BL}$ & T. aestivum \\
\hline Coker747 & Pm6 & None & $2 \mathrm{BL}$ & T. timopheevii \\
\hline Transec & $P m 7$ & None & 4BS.4BL-2R1 & Secale cereal \\
\hline Kavkaz & $\operatorname{Pm} 8$ & PI 361879 & 1RS.1BL & S. cereal \\
\hline N14 & $\operatorname{Pm} 9$ & None & $7 \mathrm{~A}$ & T. aestivum \\
\hline Wembley & $P m 12$ & None & $6 \mathrm{Bs}$ & A. speltoides \\
\hline Pm16 & Pm16 & None & $4 \mathrm{~A}$ & T. dicoccoides \\
\hline Amigo & $P m 17$ & None & 1RS.1AL & S. cereal \\
\hline $\operatorname{Pm} 24$ & $P m 24$ & None & $1 \mathrm{DS}$ & T. aestivum \\
\hline NC96BGTD3 & Pm35 & None & $5 \mathrm{DL}$ & A. tauschii \\
\hline 5-BIL29(durum) & $P m 36$ & None & $5 \mathrm{BL}$ & T. dicoccoides \\
\hline NC99BGTAG11 & $P m 37$ & None & 7AL & T. timopheevii \\
\hline 'Chancellor' & None & CI12333 & & \\
\hline
\end{tabular}

Table 2. Twelve Egyptian bread wheat cultivars and pedigrees used in this study

\begin{tabular}{|c|c|}
\hline Cultivars & Pedigree \\
\hline Gemmeiza-7 & $\begin{array}{l}\text { CMH74A.360/5x//Seri82/3/Agent CGM4611-2GM- } \\
\text { 3GM-1GM-0GM }\end{array}$ \\
\hline Gemmeiza-9 & $\begin{array}{l}\text { Ald"'S"'/Huac"'S"//CMH 74A.630/5x CGM 4583- } \\
\text { 5GM-1GM-0GM }\end{array}$ \\
\hline Gemmeiza-10 & Maya 74"'S"/On//1160-174/3/Bb/4/Chal "S"'/5/Ctow \\
\hline Gemmeiza-11 & $\begin{array}{l}\text { BUC',S"'/Kvz'"S',//7c/Seri 82/3/Giza 168/Sakha } 61 \\
\text { GM7892-2GM-1GM-0 GM }\end{array}$ \\
\hline Gemmeiza-12 & $\begin{array}{l}\text { OTS/3/SARA/THB//Vee-CMss97Y0027S-5Y-010M- } \\
\text { 010Y-010M-2Y-1M-0Y-06M-06M-0GM }\end{array}$ \\
\hline Giza-168 & MIL/BUC//Seri CM93046-8M-0Y-0M-2Y-0M \\
\hline Giza-171 & Gemmeiza-9/Sakha-93 \\
\hline Sids-12 & $\begin{array}{l}\text { BUC//7c/Ald/5/Maya74/On/1160.147/3/BB/G11/4/Chat } \\
\text { "S"'/6/Maya/vu1//Cmh 74A.630/4* sx, SD7096-4SD- } \\
\text { 1SD-0SD }\end{array}$ \\
\hline Sids-13 & $\begin{array}{l}\text { ALmaz } 19=\text { Kauz "S"'//Tsi/snb "S" ICW 94-0375- } \\
\text { 4AP-2AP-030AP-) APS-2AP-0APS-050AP-0AP-0SD }\end{array}$ \\
\hline Sids-14 & $\begin{array}{l}\text { SW8488*2/KUKUNA-CGSS01Y00081T-099M-099Y- } \\
\text { 099M-099B-9Y-0B-0SD }\end{array}$ \\
\hline Misr-1 & $\begin{array}{l}\text { Oasis/skauz//4* BCN/3/2*Pastor CMss 00Y01881T- } \\
\text { 050M-030Y-030M-030WGY-33M-0Y-0S }\end{array}$ \\
\hline Misr-2 & $\begin{array}{l}\text { SKAUZ/BAV 92. CMss } 96 \text { M03611S-1M-0105Y- } \\
\text { 010M-010SY-8M-0Y-0S }\end{array}$ \\
\hline
\end{tabular}

$$
\% \text { Gene efficacy }=\frac{\text { No. of times the gene is resistent }}{\text { Total no. of isolates }} \times 100
$$

Adult plant resistance. Evaluation of the 21 powdery mildew lines as well as the local wheat cultivars against powdery mildew disease was carried out under natural infection at adult stage in the field of Gemmeiza Research Station during the 2013 and 2014 growing seasons. The powdery mildew lines and local wheat cultivars were sown in rows $2 \mathrm{~m}$ long and $40 \mathrm{~cm}$ apart. Twenty seeds per row for each entry, with three replicates, were used. The highly susceptible 'Chancellor' was used as a check. The experiment was surrounded

Table 3. Virulence/avirulence formula and frequency and virulence percentages of 18 isolates of Blumeria graminis f. sp. tritici collected in the 2013 season on 21 powdery mildew monogenic lines

\begin{tabular}{lccc}
\hline $\begin{array}{l}\text { Virulence/ } \\
\text { avirulence formulae }\end{array}$ & $\begin{array}{c}\text { \% Frequency of } \\
\text { formulae }\end{array}$ & $\begin{array}{c}\text { Virulence } \\
\text { genes (\%) }\end{array}$ & $\begin{array}{c}\text { Virulent } \boldsymbol{P m} \\
\text { genes } \mathbf{\%} \text { ) }\end{array}$ \\
\hline 1a,3a,3f,4a,5a,7,8,9/ & 16.66 & 8 & 38.09 \\
1a,3f,5a,7,8,9/ & 55.55 & 6 & 28.57 \\
1a,3f,5a/ & 27.77 & 3 & 14.28 \\
\hline
\end{tabular}

Table 4. Virulence/avirulence formula, frequency, and virulent percentages of 34 isolates of wheat powdery mildew collected in 2014 season on 21 powdery mildew monogenic lines

\begin{tabular}{lccc}
\hline $\begin{array}{l}\text { Virulence/avirulence } \\
\text { formulae }\end{array}$ & $\begin{array}{c}\text { \% Frequency of } \\
\text { formulae }\end{array}$ & $\begin{array}{c}\text { Virulence } \\
\text { genes (no.) }\end{array}$ & $\begin{array}{c}\text { Virulent } \\
\text { genes (\%) }\end{array}$ \\
\hline 1a,3a,3b,3c,3f,5a,7,8,9,17/ & 38.23 & 10 & 47.61 \\
1a, 2, 3b, 3c,5a,7,8,9,17/ & 5.88 & 9 & 42.85 \\
1a, 3a,3b,3c,3f,5a,7,17/ & 8.82 & 8 & 38.09 \\
3a,3b,3c,3f,4a,5a,7,17/ & 5.88 & 8 & 38.09 \\
3a,3b,3c,4b,5a,7,8/ & 5.88 & 7 & 33.33 \\
1a,3a,3c,4b,8,9,17/ & 2.94 & 7 & 33.33 \\
3a,3b,3c,3f,5a,17/ & 5.88 & 6 & 28.57 \\
3c,4b,5a,7,9,17/ & 5.88 & 6 & 28.57 \\
1a,3a,5a,7,17/ & 5.88 & 5 & 23.80 \\
5a,6,7,9/ & 2.94 & 4 & 19.04 \\
7,8,9/ & 11.76 & 3 & 14.28 \\
\hline
\end{tabular}

Table 5. Percent gene efficacy of 21 powdery mildew $(\mathrm{Pm})$ genes to 18 and 34

\begin{tabular}{|c|c|c|c|c|}
\hline \multirow[b]{2}{*}{ Pm gene } & \multicolumn{2}{|c|}{2013} & \multicolumn{2}{|c|}{2014} \\
\hline & No. of copies ${ }^{a}$ & Efficacy (\%) & No. of copies ${ }^{a}$ & Efficacy (\%) \\
\hline Pmla & 0.00 & 0.00 & 14 & 41.17 \\
\hline$P m 2$ & 18 & 100.00 & 32 & 94.11 \\
\hline$P m 3 a$ & 15 & 83.33 & 13 & 38.23 \\
\hline$P m 3 b$ & 18 & 100.00 & 7 & 20.58 \\
\hline$P m 3 c$ & 18 & 100.00 & 9 & 26.47 \\
\hline$P m 3 d$ & 18 & 100.00 & 34 & 100.00 \\
\hline$P m 3 f$ & 0.00 & 0.00 & 14 & 41.17 \\
\hline$P m 4 a$ & 15 & 83.33 & 32 & 94.11 \\
\hline$P m 4 b$ & 18 & 100.00 & 29 & 85.29 \\
\hline$P m 5 a$ & 0.00 & 0.00 & 6 & 17.64 \\
\hline Pm6 & 18 & 100.00 & 33 & 97.05 \\
\hline $\operatorname{Pm} 7$ & 5 & 27.77 & 3 & 8.82 \\
\hline $\operatorname{Pm} 8$ & 5 & 27.77 & 12 & 35.29 \\
\hline $\operatorname{Pm} 9$ & 5 & 27.77 & 11 & 32.35 \\
\hline Pm12 & 18 & 100.00 & 34 & 100.00 \\
\hline Pm16 & 18 & 100.00 & 34 & 100.00 \\
\hline$P m 17$ & 18 & 100.00 & 7 & 20.58 \\
\hline Pm24 & 18 & 100.00 & 34 & 100.00 \\
\hline Pm35 & 18 & 100.00 & 34 & 100.00 \\
\hline Pm36 & 18 & 100.00 & 34 & 100.00 \\
\hline$P m 37$ & 18 & 100.00 & 34 & 100.00 \\
\hline ‘Chancellor' & 0.00 & 0.00 & 0.00 & 0.00 \\
\hline
\end{tabular}
isolates of powdery mildew at seedling stage in 2013 and 2014 seasons

${ }^{a}$ Number of times the resistance gene occurred. 
by a 1- wide border of 'Morocco' to promote homogeneous disease spread. Disease severity was scored on the flag leaf when plants of 'Chancellor' and 'Morocco' showed maximum disease severity, using the scale of Leath and Heun (1990).

\section{Results}

Three and 11 virulence/avirulence formulae with different frequencies were detected in 2013 and 2014, respectively. Virulence was detected for $\mathrm{Pm}$ genes, ranging from three to nine genes in 2013 and from three to 10 resistance genes in 2014 (Tables 3 and 4). In 2013, data (Table 3) showed that the formula 1a, 3a, 3f, 4a, 5a, 7, 8, 9/2, 3b, 3c, 3d, 4b, 6, 12, 16, 17, 24, 35, 36, 37, which comprises Gharbia and Menufia provinces, was the most virulent one $(38.01 \%$ virulence) and most frequent (16.66\% occurrence). The formulala, 3f, 5a, 7, 8, 9/2, 3a, 3b, 3c, 3d, 4a, 4b, 6, 12, 16, 17, 24, 35, 36, 37, comprising Gharbia, Dakalia, and Beheira provinces, was the most frequent accounting for $55.55 \%$ of occurrence, but it was less virulent ( $28.57 \%$ virulence). The isolates obtained from Qalubia, comprised by the formula 1a,3f,5a/7, 8, 9/2, 3a, 3b, 3c, 3d, 4a, 4b, 6, 12, 16, 17, 24, $35,36,37$, showed the least virulence $(14.28 \%)$.

However in 2014, data (Table 4) revealed great differences in virulence among the collected 34 powdery mildew isolates, ranging between 14.28 to $47.61 \%$. The formula 1a, 3a, 3b, 3c, 3f, 5a, 7, 8, 9, $17 / 2,3 \mathrm{~d}, 4 \mathrm{a}, 6,12,16,24,35,36,37$ was the most virulent one (47.61\%), accounting for $38.23 \%$ of occurrence. The lowest occurrence of virulence formulae were obtained from Qalubya and Dakahlia

Table 6. Assessment of disease on wheat cultivars and powdery mildew lines ${ }^{\mathrm{a}}$

\begin{tabular}{|c|c|c|}
\hline \multirow[b]{2}{*}{ Cultivar or line } & \multicolumn{2}{|c|}{ Disease assessment $^{\mathbf{b}}$} \\
\hline & 2013 & 2014 \\
\hline Gemmeiza-7 & 9 & 8 \\
\hline Gemmeiza-9 & 8 & 7 \\
\hline Gemmeiza-10 & 8 & 7 \\
\hline Gemmeiza-11 & 9 & 8 \\
\hline Gemmeiza-12 & 9 & 8 \\
\hline Giza-168 & 9 & 8 \\
\hline Giza-171 & 9 & 8 \\
\hline Sids-12 & 8 & 6 \\
\hline Sids-13 & 9 & 9 \\
\hline Sids-14 & 9 & 9 \\
\hline Misr-1 & 9 & 8 \\
\hline Misr-2 & 9 & 8 \\
\hline Pmla & 7 & 8 \\
\hline $\operatorname{Pm} 2$ & 0 & 0 \\
\hline Pm3a & 0 & 6 \\
\hline Pm3b & 0 & 6 \\
\hline $\operatorname{Pm} 3 c$ & 0 & 7 \\
\hline Pm3d & 0 & 0 \\
\hline Pm3f & 0 & 0 \\
\hline$P m 4 a$ & 0 & 0 \\
\hline$P m 4 b$ & 0 & 9 \\
\hline Pm5a & 0 & 8 \\
\hline Pm6 & 0 & 0 \\
\hline $\operatorname{Pm} 7$ & 0 & 6 \\
\hline $\operatorname{Pm} 8$ & 8 & 6 \\
\hline $\operatorname{Pm} 9$ & 7 & 7 \\
\hline Pm12 & 0 & 0 \\
\hline Pm16 & 0 & 0 \\
\hline Pm17 & 0 & 0 \\
\hline $\operatorname{Pm} 24$ & 0 & 0 \\
\hline Pm35 & 0 & 0 \\
\hline Pm36 & 0 & 0 \\
\hline Pm37 & 0 & 0 \\
\hline 'Chancellor' & 9 & 9 \\
\hline
\end{tabular}

a Assessment of 21 powdery mildew lines and 12 local Egyptian bread wheat cultivars against natural infection of powdery mildew at the adult stage in 2013 and 2014 seasons.

${ }^{\mathrm{b}}$ Disease assessment was recorded on the flag leaf. provinces, i.e., 5a, 6, 7, 9/1a, 2, 3a, 3b, 3c, 3d, 3f, 4a, 4b, 8, 12,16, $17,24,35,36,37$ (19.04\% virulence) accounting for $2.94 \%$ occurrence and formula 7, 8, 9/1a, 2, 3a, 3b, 3c, 3d, 3f, 4a, 4b, 5a, 6, 12, $16,17,24,35,36,37$ (14.28\% virulence and accounting for $11.76 \%$ occurrence).

The efficacy percentage of $21 \mathrm{Pm}$ genes for resistance against 18 and 34 isolates of $B$. graminis f. sp. tritici in 2013 and 2014, respectively, was also determined (Table 5). The obtained data revealed that Pm genes Pm3d, Pm12, Pm16, Pm24, Pm35, Pm36, and Pm37 remained completely effective for all isolates. High virulence for genes Pmla, Pm3f, Pm5a, Pm7, Pm8, and $P m 9$ were detected, with efficacy percentage ranging from 0.00 to $27.77 \%$ in 2013 and 8.82 to $41.17 \%$ in 2014. Slight virulence was detected for genes Pm2, Pm4a, and Pm6. Intermediate virulence was detected on $\mathrm{Pm} 3 b, \mathrm{Pm} 3 \mathrm{c}$, $P m 4 b$, and $P m 17$. Data in Table 6 revealed that, at the adult stage, genes Pm2, Pm3d, Pm3f, Pm4a, Pm6, Pm12, Pm16, Pm17, Pm24, $P m 35, P m 36$, and $P m 37$ were totally effective under natural infection conditions over the two years. Responses of the remaining $P m$ genes fluctuated between resistant in one year to susceptible in another or susceptible in the two years, as the control 'Chancellor'. Local wheat varieties showed high susceptible responses to powdery mildew disease.

\section{Discussion}

Survey for wheat powdery mildew in Delta Egypt during growing seasons 2013 and 2014 indicated the presence of the disease in the wheat-growing areas in five provinces of Delta Egypt. One of the most important steps in breeding programs for powdery mildew resistance in wheat is the identification of the prevailing virulent pathotypes of the pathogen in the region and resistance genes. A toal of 21 $P m$ genes were evaluated for resistance against 52 isolates of $\mathrm{B} . \mathrm{gra}$ minis f. sp. tritici, collected through the two years.

The obtained data revealed that most of the virulent pathotypes were detected from those collected from Gharbia and Menufia provinces of Delta Egypt more often than from the other provinces. This may be due to growing wheat repeatedly in the same area every year, leading to increasing concentrations of the fungus chasmothecia in the soil and, consequently, increasing pathogenesis of the fungus. The variability of the pathogen population may be due to the sexual phase that produces more virulent pathotypes.

Under natural field infection, Pm2, Pm3d, Pm3f, Pm4a, Pm6, Pm12, Pm16, Pm17, Pm24, Pm35, Pm36, and Pm37 were completely effective against powdery mildew at the adult stage. In contrast, all the local cultivars showed highly susceptible responses to powdery mildew. In a previous study, El-Shamy et al. (2012) evaluated four wheat cultivars, i.e., Sakha-93, Gemmeiza-7, Gemmeiza10, and Giza-160, as a check to artificial inoculation of powdery mildew under field conditions. The tested wheat cultivars showed susceptible responses to powdery mildew, with fluctuating values that ranged from 35 to $87 \%$ in 2010 and from 6 to $15 \%$ in 2011 . The foregoing data clarified that the Egyptian wheat cultivars may lack resistance genes and can be modified by inserting genes resistant to powdery mildew through a special breeding program. Identifying $P m$ genes that already exist in such cultivars may precede the work in the breeding program. Already, this step was carried out by Emara et al. (2016), who identified three resistant $P m$ genes, $P m 24$, $P m 35$, and $P m 37$, in 13 local wheat cultivars, using simple sequence repeat markers. They found that none of the three genes were present in the studied wheat cultivars.

\section{Acknowledgments}

We thank C. Cowger, small grains pathologist, USDA-ARS, Department of Plant Pathology, North Carolina State University, who provided us with the monogenic line differentials of powdery mildew.

\section{Literature Cited}

Alam, M. A., Xue, F., Wang, C., and Ji, W. 2011. Powdery mildew resistance genes in wheat: Identification and genetic analysis. J. Mol. Bio. Res. 1: 20-39.

Browder, L. E. 1972. A multi-culture inoculation system for study of host-parasite relationships. Plant Dis. Rep. 56:847-849. 
Chen, Y., Hunger, R. M., Carver, B. F., Zhang, H., and Yan, L. 2009. Genetic characterization of powdery mildew resistance in U.S. hard winter wheat. Mol. Breed. 24:141-152.

Costamilan, L. M. 2005. Variability of the wheat powdery mildew pathogen Blumeria graminis f. sp. tritici. Fitopatol. Bras. 30:420-422.

El-Shamy, M. M., Sallam, M. E. A., and Awad, H. M. F. 2012. Powdery mildew infection on some Egyptian bread wheat cultivars in related to environmental conditions. J. Agric. Sci. 3:363-372.

Emara, H. M., Omar, A. F., El-Shamy, M. M., and Mohamed, M. E. 2016. Identification of Pm24, Pm35 and Pm37 in thirteen Egyptian bread wheat cultivars using SSR markers. Ciência Agrotecnol. 40:155-163.

Green, G. J. 1966. Stem rust of wheat, ray and barley in Canada in 1965. Can. J. Plant Dis. Surv. 46:27-32.

Huang, L. S., Zhang, D. Y., Liang, D., Yuan, L., Zhao, J. L., Hu, G. S., Du, S. Z., and $\mathrm{Xu}, \mathrm{X}$. G. 2013. Continuous wavelet analysis for diagnosing stress characteristics of leaf powdery mildew. Int. J. Agric. Biol. 15:34-40.

Leath, S., and Heun, M. 1990. Identification of powdery mildew resistance genes in cultivars of soft red winter wheat. Plant Dis. 74:747-752.

Liu, S., Griffey, C. A., and Saghai Maroof, M. A. 2001. Identification of molecular markers associated with adult plant resistance to powdery mildew in common wheat cultivar Massey. Crop Sci. 41:1268-1275.
Mago, R., Tabe, L., McIntosh, R. A., Pretorius, R., Paux, E., Wicker, T., Breen, J. Lagudah, E. S., Ellis, J. G., and Spielmeyer, W. 2011. A multiple resistance locus on chromosome arm 3BS in wheat confers resistance to stem rust $(\mathrm{Sr} 2)$, leaf rust ( $L r 27)$ and powdery mildew. Theor. Appl. Genet. 123:615-623.

Maxwell, J. J., Lyerly, J. H., Cowger, C., Marshall, D., Brown-Guedira, G., and Murphy, J. P. 2009. MlAG12: A Triticum timopheevii-derived powdery mildew resistance gene in common wheat on chromosome 7AL. Theor. Appl. Genet. 119:1489-1495.

Niewoehner, A. S., and Leath, S. 1998. Virulence of Blumeria graminis f. sp. tritici on winter wheat in the Eastern United States. Plant Dis. 82:64-68.

Peusha, H., Enno, T., and Priilinn, O. 2000. Chromosome location of powdery mildew resistance genes and cytogenetic analysis of meiosis in common wheat cultivar Meri. Hereditas 132:29-34.

Reader, S. M., and Miller, T. E. 1991. The introduction into breed wheat of a major gene for resistance to powdery mildew from wild emmer wheat. Euphytica 53: 57-60.

Samborski, D. J., and Dyck, P. L. 1976. Inheritance of virulence in Puccinia recondita on six back cross lines of wheat with single genes for resistance to leaf rust. Can. J. Bot. 54:1666-1671.

Szunics, L., and Szunics, L. U. 1999. Wheat powdery resistance genes and their application in practice. Acta Agron. Hung. 47:69-89. 